\title{
Building interfirm leadership: A relational identity perspective
}

\author{
Bin Hao \\ East China University of Science and Technology \\ Yanan Feng (Corresponding author) \\ University of Nottingham \\ Jiangfeng Ye \\ Anhui University
}

\begin{abstract}
While leadership has been recognized as an approach to facilitating network orchestration, little is known about the mechanism through which a hub firm enhances interfirm leadership. Grounded on the theory of social identity and network orchestration, we develop a framework of the enhancement of interfirm leadership, proposing that the tendency of building leadership rests on the hub firm's ability to shape the partners' relational identity. We identify three types of role-adoption that indicate seven actions a hub firm might take to establish such an identity. We suggest that the mechanism through which leadership emerges is contingent on relationship duration, dependence asymmetry, and competition intensity.
\end{abstract}

Keywords: network orchestration, interfirm network, hub firm, interfirm leadership, relational identity 


\section{Introduction}

Since interfirm networking has emerged as an overwhelming trend of business development (Gulati, 1998; Zaheer \& Bell, 2005), network orchestration becomes increasingly crucial for strategy theory and practice. By implicitly or explicitly recognizing the importance of hub firms in network orchestration, scholars have explored, for example, how a hub firm coordinates and orchestrates network activities (Dhanaraj \& Parkhe, 2006; Doz, Olk, \& Ring, 2000; Vanhaverbeke, Gilsing, \& Duysters, 2012), imposes power over partners (De Reuver \& Bouwman, 2012; Sydow \& Windeler, 1998), promotes network knowledge learning (Lipparini, Lorenzoni, \& Ferriani, 2014; Munari, Sobrero, \& Malipiero, 2012), and extends reciprocity with partners (Provan, Fish, \& Sydow, 2007; Lee, Mun, \& Park, 2015). Yet network research has rarely engaged with the significant challenge regarding network orchestration: the enhancement of hub firms' leadership across organizational boundaries.

A hub firm, which is conceptualized as "one that possesses prominence and power gained through individual attributes and a central position in the network structure" (Dhanaraj \& Parkhe, 2006: 659), takes charge of value creation for both itself and the whole network (e.g., Toyota in its production network, and Walmart in its supplier network). The differences in terms of characteristics and capabilities for network orchestration result in the fact that some hub firms outperform others in co-creating value with their partners (Müller-Seitz, 2012; Provan et al., 2007). The reasons are, first, the hub firm's capabilities and position advantages may influence partners' network behaviors (formal influence); second, the hub firm's behaviors and attitudes for network integration and communication may affect partners' perception and identity (informal influence) (Zeng \& Chen, 2003). These imply a leadership approach to secure the effectiveness of network orchestration (Gawer \& Cusumano, 2002; Perrons, 2009; Gawer, 2014), as we conceptualize it here as interfirm leadership, referring to 
the formal and informal influence a hub firm holds over its partners.

To clearly demonstrate interfirm leadership, we need to look deeply into the black box of network orchestration activities. One example of such activities can be the integration of different knowledge and diverse interests among partners. Since the coordination and combination of one another's resources is related to both formal capability advantage and informal reciprocity, a hub firm will more easily obtain status if it creates and extracts value with a more inclusive view (Koschmann, Kuhn, \& Pfaffer, 2012). Another example refers to the hub firm's role in exploring future direction of strategic business. Because it is the hub firm that significantly determines the whole network's recent and future performance, its capacity to continue advancing technologies and developing new markets would inevitably affect its partners' identification of it as an enduring leader (Tellis \& Golder, 1996). However, current studies on network orchestration provide few insights into demonstrating the mechanism through which interfirm leadership may be enhanced. In this paper, we develop a general model to solve this issue.

We consider the enhancement of interfirm leadership as an interactive process between the hub firm and its partners based on Bitektine's (2011) notion that an actor's legitimacy and status is obtained on the basis of an evaluators' judgment and identity. Our focus here is partners' relational identity - a firm's self-definition in terms of its partnership with other firms (Hogg, van Knippenberg, \& Rast, 2012). We present our analysis in a way that reveals how relational identity may be shaped to support the enhancement of interfirm leadership. We draw special attention to centralized networks (as opposed to loosely connected networks such as R\&D alliances which consist of potential players vying for a coordinating role among peers) in which one hub firm possesses prominence over other partner firms and each of these partners undertakes a small part of the production or service tasks coordinated and integrated by the hub firm. 
Our study will have significant theoretical and practical importance. Theoretically, our study can provide novel insights into the mechanism through which interfirm leadership can be enhanced in centralized networks. In addition, while existing literature has indicated the need to explore identity in interfirm contexts (e.g., Zeng \& Chen, 2003; Gawer \& Phillips, 2013), our study can contribute to this line of inquiry by exploring the mechanism through which relational identity can be shaped in the process of network orchestration. Practically, conclusions of this research will allow us to better understand how hub firms should orchestrate their networks to secure interfirm leadership. We first explain the background of, and the need for, interfirm leadership, followed by a demonstration of how relational identity can be integrated into the understanding of interfirm leadership. We then elaborate on the enhancement of interfirm leadership, explaining how a hub firm obtains relational identity by involving itself in joint activities. We conclude by presenting contributions and directions for future research.

\section{The call for interfirm leadership}

Interfirm cooperation literature has revealed a number of activities through which the relationship benefits collaborative firms in non-centralized networks, such as reciprocity (Dyer \& Singh, 1998; Luo, 2008), joint problem solving (Uzzi, 1997), and embeddedness (McEvily \& Marcus, 2005). While these studies focused predominantly on non-hierarchical, interdependent interfirm relationships, they may not explain the situations in hierarchical, centralized networks characterized by dependence asymmetry (Lee et al., 2015). Dependence asymmetry entails the power to integrate interfirm activities to fulfill its own goal, and also the responsibility for creating value for the entire network (Dyer \& Nobeoka, 2000; Emerson, 1962; Provan \& Kenis, 2008). A hub firm influences the network by designing rules of action, coordinating interfirm interests, and developing network goals (Paquin \& Howard-Grenville, 
2013). By labeling their own characteristics and activities in the networks, hub firms clearly define for their networks who they are and where they are going. This may later invite interfirm biases that affect prospective partners' willingness to enter the network and to commit to the relationships after entering (cf. Rusbult, Verette, Whitney, \& Slovik, 1991). In general, high-quality partner firms have the opportunity to select certain hub firm(s) instead of others. For instance, Leica Camera's advantageous technology ensures that it could obtain power in selecting mobile phone manufactures. They would prefer to build relationships with those hub firms that care about their stakeholders rather than focusing solely on their own interests (Scott \& Lane, 2000).

Further, network-level competition necessitates the selection of a stronger network leader. While customers, suppliers, investors and communities join forces to improve their offerings, market competition switches from the firm level to the network level (Moore, 1993). The hub firm carries out the leadership function (Lorenzoni \& Baden-Fuller, 1995), striving to take over market share and realize stakeholders' market value. A stronger network leader ensures that value can be created and extracted efficiently and fairly (Ariño \& Ring, 2010). For example, Walmart is considered to be more capable of optimizing its supplier network than rivals.

Finally, the hub firm's capacity for network orchestration can be a crucial factor leading to network success. A hub firm's capabilities, such as system integration and exploration, determine how many benefits partners may obtain through participation, thus affecting their judgment of the relationships. Also, a hub firm's endeavors in developing informal relationships significantly influence partners' willingness to follow it (e.g., Asanuma, 1989). The challenge to a hub firm, then, is to build an inclusive network that enhances partners' willingness to follow its lead, and that entails extensive collaboration and value co-creation.

While we believe that mainstream research has thoroughly explored the leader role of a 
hub firm in orchestrating or governing the network (e.g., Hagedoorn, 1995; Provan et al., 2007), the issue of how the leadership function is fulfilled has yet to be explored. In the context of a centralized network, hub firms are widely acknowledged as "orchestrators" or “gatekeepers" (Munari et al., 2012; Paquin \& Howard-Grenville, 2013). While partner firms may not determine the coordination and governance process, they may choose their own ways of embedding into such a process. The interaction within asymmetric relationships reflects the extent to which the hub firm's role as a network leader can be acknowledged. Thereafter, interfirm leadership of a hub firm, in our view, is determined by both network orchestrating activities and partners' identification of such a leadership state.

Interfirm leadership, as we conceptualize it here, refers to the formal and informal influence a hub firm exerts over partner firms within a network, from which collaborative efforts can be well orchestrated toward the intention of value co-creation. This definition explicitly identifies the leadership of an organization rather than an individual. For example, the leader of a platform ecosystem will also need to show its leadership in increasing platform traffic. By borrowing the term 'influence' from individual-level leadership, we mean here not only the power a hub firm acquires from an advantageous network position or resources, but also the informal influence partner firms may have exerted on them through the hub firm's trustworthy, altruistic behaviors (Perrons, 2009). Here, power is defined as the extent to which one network actor enforces decisions over others (De Reuver \& Bouwman, 2012). Within the approach of interfirm leadership, a partner firm does not passively accept the power of the network leader (i.e., the hub firm), but, as an admirer, follows the hub firm's lead in proceeding with network development.

Interfirm leadership is not considered as an approach to develop existing leadership theory, but a perspective to reflect the management challenge for hub firms in asymmetric network relationships (Dhanaraj \& Parkhe, 2006; Sydow, Lerch, Huxham, \& Hibbert, 2011). The 
evaluation of interfirm leadership is thus understood in terms of the outcome of the hub firm's strategic actions rather than an individual's subjective experience or psychological state (Hogg et al., 2012). Instead of treating network orchestration as a top-down activity, we conceptualize interfirm leadership as a natural way of pushing partners in the direction in which the hub firm wishes to go. Interfirm leadership demonstrates the situations in which partners are more satisfied collaborating with a certain hub firm than with others. From this point of view, interfirm leadership departs from our understanding of market leadership which explains the market position of a company in terms of profitability and market share (Tellis \& Golder, 1996), as well as reputation which captures the perceived ability of the firm to create value for customers and other stakeholders (Bitektine, 2011).

\section{The role of identity in shaping interfirm leadership}

Social judgment perspective emphasizes the importance of the followers' perception and identification of the leader's status (Bitektine, 2011). Accordingly, a hub firm may have to utilize its power in a way that stimulates a shared relational identity. This section discusses the role of identity in shaping interfirm leadership.

\subsection{Interfirm relational identity}

Social identity is conceptualized as "an individual's self-concept which derives from his knowledge of his membership of a social group together with the emotional significance attached to that membership" (Tajfel, 1974: 69). Such knowledge typically includes his perception about the group's central, distinctive, and enduring qualities and thus, distinguishes his own group from others (Brickson, 2007). At the individual level, identity is a cognitive image held by a member of an organization (Dutton, Dukerich, \& Harquail, 1994). Still, there are plenty of cases in which members of an organization share a collective 
view_some level of consensus - in recognizing the organization, which is widely acknowledged as organizational identity (Scott \& Lane, 2000). From the perspective of interfirm network (compared to a firm), such a collective view reflects organizational members' conception of the firm as an individual actor set apart from others, and as part of a larger whole or collective (Brickson, 2007). Since firms are widely endowed with subjective characteristics and states such as trust, bonding, benevolence, and commitment (Folta, 1998; Schreiner, Kale, \& Corsten, 2009), it is acceptable to consider the firm as an actor that shapes identity. Taking the firm as a basic unit of analysis, the issue of identity refers to the self-conception of the firm as part of a series of network relationships based on mutual dependencies (Kogut, 2000). As Scott and Lane (2000) pointed out, dependency has implications for identification. Partner identification may derive from the perceptions that network actors rely on each other in terms of knowledge sharing, process integration, or financial investment, implying the importance of identity for effective partnership operation (Koschmann et al., 2012).

To capture how firms may define their identity in terms of their relationship with other firms, we borrow from Hogg, van Knippenberg, and Rast (2012), introducing the concept of interfirm relational identity to demonstrate a firm's self-definition in terms of its partnership with other firms. Relational identity focuses on formal and informal reciprocities between self (the organization) and others, concerning the authorization of self to engage in network intercourses as a collectivity to undertake rights and responsibilities about interfirm collaboration (Czarniawska, 1997). According to Sluss and Ashforth (2007), relational identity at the individual level integrates role-based and person-based identities. Similarly, interfirm relational identity captures a partner firm's self-concept of its role in the interfirm relationship and the qualities of its hub firm. It appears between the hub firm and a partner rather than among the whole network because it is the dyadic interaction that leads to 
identification with a relationship. When a hub firm encourages relational identification, it will enhance the partner firms' self-efficacy (Walumbwa \& Hartnell, 2011). Under certain conditions, interfirm relational identity may converge with identification at the network level through cognitive or behavioral mechanisms such as social influence and behavioral sense-making (Sluss \& Ashforth, 2008), demonstrating the importance of relational identity on network orchestration. In contrast with interpersonal-level identity, interfirm relational identity reflects self-conception at the collective level (Hogg et al., 2012), defining collective perception about the firm's reciprocal, enduring interaction with other firms. As a firm normally resides in a series of relationships within the interfirm network, the perception of one specific relationship is determined by the extent of significance such a relationship contributes to the well-being of the individual firm. Therefore, interfirm relational identity emphasizes the self-perceptions about partnerships the firm perceives as meaningful relationships. From this perspective, interfirm relational identity is not only an outcome of organizational members' collective self-conception, but also a reflection of the firm's strategic arrangements. For example, Foxconn's relational identity in its relationship with Apple could be deemed more important than its relational identity in relationships with other smaller outsourcers as Apple represents a major order source and plays a role of strategic importance to Foxconn (cf. Hogg et al., 2012). In other words, a deeper business connection leads to greater significance of relational identity.

\subsection{Relational identity and interfirm leadership}

Interfirm relational identity embeds in the relationship in which both self and partners become involved, commit, and benefit. It guides organizational actions, including the treatment of interfirm relationships (Brickson, 2007). In our specific context of asymmetric relationships, smaller entities are inclined to perceive themselves in terms of the partnership 
with hub firms through which they obtain status (Gnyawali \& Madhavan, 2001), and are largely motivated to support interfirm knowledge flow and resource integration. From this perspective, relational identity enhances partners' willingness to acknowledge the hub firm's leading status and follow its lead. Also, the essence of relational identity lies in the interaction with others from which individual firms generate reflexive awareness about self and the relationship (Gioia, Schultz, \& Corley, 2000). Repeated interaction bonds partners together through ties of trust and reciprocity (Gulati \& Singh, 1998), thus conferring legitimacy on the hub firm and bolstering its status as network leader (Perrons, 2009).

Further, interactions fostered on the basis of relational identity help partners get access to information about the obstacles and solutions of the collaboration (e.g., Grönroos, 2011). During the interaction, partners' attitudes toward the hub firm can improve, and anxiety about knowledge and interest misappropriation can diminish (Wright, Aron, McLaughlin-Volpe, \& Ropp, 1997), thus reducing potential resistance to the exertion of formal and informal influence (Gulati \& Sytch, 2007). Furthermore, partners' relational identity can be helpful in shaping shared cognition about the hub firm's vision (Hogg \& Reid, 2006), leading to a deeper embeddedness into the hub firm's strategic plans and actions. The exertion of formal and informal influence can then be viewed as a beneficial tool for value co-creation rather than as an unacceptable means of controlling interfirm communications, thereby legitimizing the hub firm's leadership behavior.

Proposition 1: Relational identity is positively related to interfirm leadership. Specifically, the strength of relational identification between a hub and a partner firm is positively related to a) the hub firm's network status, and b) the hub firm's formal and informal influence on the partner firm. 


\section{The enhancement of interfirm leadership}

Relational identity acts as a basis to demonstrate the enhancement of interfirm leadership. The remaining issue, then, is what specific types of actions the hub firm may conduct to shape partners' relational identity so that interfirm leadership may be acknowledged. To answer this question, we suppose that the effect of the hub firm's activities on shaping partners' relational identity is determined by the role played by the hub firm when conducting such activities. Here we identify three types of roles a hub firm may play as a network leader as indicated in previous literature (Frances \& Garnsey, 1996; Schreiner et al., 2009; Perrons, 2009): director, integrator, and explorer. "Director" reflects the hub firm's endeavors to help partners with technical or management issues (Schreiner et al., 2009), including: involvement in partners' problem-solving processes and guidance on partners' goal-framing. "Integrator" demonstrates the hub firm's role in coordinating and integrating network resources and activities (Frances \& Garnsey, 1996; Gulati \& Singh, 1998), relating to three relationship practices: inclusion of diverse interests in decision-making, pursuit of synergy in knowledge integration, and endurance of environmental dynamics. While "director" and "integrator" represent the maintenance of existing activities in the relationship, "explorer" stresses the exploration and exploitation of future direction for the relationship (Perrons, 2009). The hub firm's role as an explorer refers to two practices: exploration of new market opportunities and development of novel technologies.

We offer ways to identify the mechanism through which interfirm leadership may be shaped, as summarized in Figure 1, showing specific practices the hub firm may conduct to develop the partners' relational identity, which in turn, helps shape interfirm leadership.

Insert Figure 1 about here.

\subsection{The hub firm's role-plays in pursuit of interfirm leadership}




\subsubsection{The role of the hub firm as a director}

The role of the hub firm as a director involves guiding interrelated activities for the benefit of the collaborative relationships with partners (Koschmann et al., 2012). Hub firms normally hold capability advantages over partners in solving technical or management problems and in framing long-term strategies. Through directing partners' process and strategic issues, a hub firm could obtain affirmation and aspiration, thus laying foundation for shaping relational identity (Sluss \& Ashforth, 2007). Thereafter, the hub firm can easily demonstrate its leadership by enforcing decisions over partners.

Involvement in partners' problem-solving processes. A hub firm normally possesses capabilities to engage in extensive interactions in terms of problem-solving (Lipparini et al., 2014). By investing time, energy and other resources in exchange relationships, the hub firm may help to improve partners' revenue-generating capacity (Grönroos, 2011), which promotes partners' positive perception of the relationships. In particular, when the problem to be solved is ill-structured or contains many unknown elements, the hub firm's extensive knowledge base can benefit partners strategically by increasing the potential to create new offerings (e.g., Perrons, 2009), thus stimulating partners' identification of the relationships. Because the problems faced by partner firms concern their high expectations, such involvement helps to shape the impression that they are in a collective with common goals and interests (i.e., relational identity) (Koschmann et al., 2012). It could then facilitate the exercising of power (Gaski, 1984), leading to the situations in which the hub firm's increased requirements (e.g., improving quality, raising efficiency) are met automatically and legitimately.

Further, the hub firm nurtures the transfer, recombination and creation of specialized knowledge by taking charge of knowledge-enhancing practices (Lipparini et al., 2014). Such specialized knowledge may be specifically applied to the interaction with the hub firm and 
could hardly be considered for other use. It thus strengthens partners' dependence on their relationships, thereby motivating them to develop relationship-specific skills in grounding their relational identity. For example, when Intel decided to adopt a new packaging technology for its Pentium II system, it chose Imoko Composites of Japan as the supplier, with whom it had worked in organizing a joint R\&D team (Perrons, 2009). As the technology was developed specifically for Intel's product, Imoko was emotionally bound together with Intel in following the trajectory of such technology. Under such circumstances, the partners are locked into the hub firm's routines of business extension, thus increasing the possibility of compliance.

Proposition 2: Being involved in partners' problem-solving processes helps create a relational identity in ways that facilitate the enhancement of interfirm leadership.

Guidance on partners' goal-framing. From the perspective of an individual firm, goal-framing refers to the motivational force that affects behaviors and the consequences of activating an overarching goal (Lindenberg \& Foss, 2011). The activation of a focal goal influences the way the firm searches, selects and processes information, and how it may act to fulfill the goal, thus creating "a frame within which all other processes take place" (Lindenberg, 2008: 672). The involvement in partners' goal-framing can be helpful in strengthening interfirm strategic fit (Zajac, Kraatz, \& Bresser, 2000), developing compatible goals, and forming an integrative strategy paradigm. The partners then identify the relationships because of the consensus of goals (Scott \& Lane, 2000). Also, goal-framing demonstrates high extent of contact with the hub firm and high extent to which the relationship with the hub firm contributes to self-esteem and self-distinctiveness (Dutton et al., 1994), thereby increasing partner firms' motivation to construct and enact relational identity. With the hub firm's guidance of goal-framing goes on into more specific activities, a 
multi-level connection (e.g., strategy, process, and governance) which suggests a community of common destiny can be expected (cf. Gawer and Phillips, 2013), thus further enhancing partners' identification of the relationships. Consequently, both the hub firm and the partners would strengthen their network ties with which to perceive closeness. According to Lindenberg and Foss (2011), goal-framing can be helpful in generating joint motivation. It thus positively influences partners' network inputs to and identification of the relationships. Since joint motivation reduces opportunistic tendencies, costly control mechanisms can be substituted with spontaneous information exchange. Therefore, instead of using the power for hierarchical control (Ring \& Van de Ven, 1992), the hub firm as a network director strives to coordinate and correct partners' strategic direction and promote information sharing. In case that the use of power (e.g., helping to charter the way forward) benefits both sides, it will foster adaptive advantage (Dunbar, 2003) by bringing together diverse information access and the expertise for dealing with that information, thus highlighting the hub firm's role in leading network activities.

Proposition 3: Participating in partners'goal framing helps create a relational identity in ways that facilitate the enhancement of interfirm leadership.

\subsubsection{The role of the hub firm as an integrator}

The hub firm as an integrator refers to its role in bringing together expertise, knowledge, interests, and product components, as well as in transferring and processing information about environmental dynamics. The way a hub firm integrates the network system is associated with how much value can be created and distributed (e.g., Frances \& Garnsey, 1996). By making a bigger cake rather than appropriating partners' interests, the hub firm depicts a win-win landscape that encourages trust and commitment. System integration as a proxy of centripetal force draws network actors together toward a shared relational identity 
(Koschmann et al., 2012). Partner firms enjoy the benefits created by the hub firm, while contributing to the network by supplying advanced components and sharing knowledge for technology improvement. Thereafter, the hub firm as an integrator legitimately exerts influence over partners. Its endeavors to control the relationship are thus acknowledgeable. Figure 1 describes three ways in which the hub firm acts as an eligible integrator, as discussed in detail in the following sections.

Inclusion of diverse interests in decision-making. Network actors collaborating or working together have a stake in each other's actions (Savage, Nix, Whitehead, \& Blair, 1991). Partners' potential action is mostly the outcome of the hub firm's decision-making in terms of the issues closely associated with their own interests. A violation of such interests may lead to mistrust and opportunistic behaviors because partners are likely to take actions when they perceive their expected interests are not going to be achieved (Rowley \& Moldoveanu, 2003). In order to exploit the potential of the relationships and to avoid conflict, the hub firm may need to include diverse interests when making decisions in relation to the orchestration of the relationships.

An inclusive interests structure entails consistency and compatibility of actions (Merton, 1936), implying a partial suspension of moral hazard (Lindenberg \& Foss, 2011) and an increase of expectations of the relationship. In this sense, the hub firm projects an image to the partners that clearly conveys their conception of the relationships, thus communicating the sense of relational identity (Gioia et al., 2000). The integration of interests also entails deep engagement, suggesting a good opportunity for the hub firm to transfer information about the threat of market competition and the requirement of strategic change. Based on this engagement process, partners improve their perception of the hub firm's image from their idiosyncratic interpretations, thereby exerting indirect effects on the identification of their 
relationships by increasing inputs (Zhu \& Yoshikawa, 2015). Consequently, it may lead to the extension of relational identity that facilitates the shift of pre-existing interests by exploring alternatives (Lindenberg \& Foss, 2011), which lays the foundation for interfirm leadership.

In addition, because past experiences provide a pre-existing orchestrating mechanism for the future (Rowley \& Moldoveanu, 2003), the identity led by interests integration in the past is more likely to shape the perception of subsequent actions. The partners are then more likely to generate understanding of the hub firm's leading status (Hogg et al., 2012). Therefore, the hub firm will cost less in maintaining the relationship, while obtaining partners' relational identity to further integrate knowledge across boundaries.

Proposition 4: The inclusion of diverse interests in decision-making helps create a relational identity in ways that facilitate the enhancement of interfirm leadership.

Pursuit of synergy in knowledge integration. The fundamental challenge of value co-creation in interfirm contexts is to realize synergy for knowledge integration across organizational boundaries. One way to enhance interfirm leadership is then to maximize the effect of synergy so that knowledge from the network can be well-integrated. A hub firm normally has access to more and better resources and opportunities than other network actors (Gnyawali \& Madhavan, 2001), suggesting more options for knowledge integration. The multiplexity of network ties surrounding the hub firm represents different types of relationships that can be used for knowledge searching and integration (Kenis \& Knoke, 2002), thereby creating an opportunity structure (Sydow \& Windeler, 1998) that facilitates synergies of diverse knowledge within the network. It thus helps enhance partners' perception of themselves as part of the network relationships. As Gioia et al. (2000) indicated, identity involves interactions and interrelationships among different network participants. In the process of pursuing synergy, partners receive feedbacks regarding the fulfillment of 
expectations in the network, thus affording a benchmark against which they can compare their own sense of relationship benefits and shape their identification of the relationships. Moreover, partner firms in the network are distinct from other outside entities because coordination and integration are situated physically in locality, which demonstrates a sense of belonging and identity. Such an identity implies a moral order and rules of exclusion (Kogut \& Zander, 1996), thus enhancing partners' self-conception of their roles in the relationships. In the frame of knowledge integration, the hub firm can not only embed the ways of sharing, complimenting, and synchronizing into the product architecture, but, as an integrator, enables groupings of partners to compete favorably against each other for network offerings (Anderson, Håkansson, \& Johanson, 1994). Such benefits lead the partners to shape an enhanced identification of the hub firm as a network leader. Moreover, the synergistic practices can be considered as a proxy of a direct exercise of influence, which in turn, allows for the continuing asymmetry of power (Frances \& Garnsey, 1996). We can thus expect that the more capable of developing network ties and designing product architecture for integrating and utilizing those ties the hub firm is, the higher the status it can obtain.

Proposition 5: The pursuit of synergy in knowledge integration helps create a relational identity in ways that facilitate the enhancement of interfirm leadership.

Endurance of environmental dynamics. While a central position provides the hub firm with power (Gnyawali \& Madhavan, 2001) and the access to diverse knowledge, it also assigns the responsibility of coping with environmental dynamics. The hub firm acts as a bridge to connect the final product market and the network participants through information processing and distributing. How environmental dynamics may be recognized and embedded into the strategy paradigm significantly determines the future of the whole network (e.g., Suarez \& Lanzolla, 2007), which closely relates to partners' perceptions and identity. For example, in 
the face of increasing demands on smart phones, Nokia's strategy failure in recent years has had a hugely detrimental impact on its suppliers, while Samsung's success in the competitive strategy of its mobile phone business has benefited its suppliers in terms of performance and technology improvement (cf. Moore, 1993).

According to Gal-Or (1985), the more challenging the environmental dynamics, the more reluctant network actors are to commit to a long-term relationship. The hub firm may thus face double challenges under such circumstances (i.e., from the environment and the partner firms). Its determination to withstand the changes in technological and market domains could then be especially helpful in shaping partners' positive judgment and evaluation of the hub firm.

A capable leader may transform threats into opportunities and grasp those opportunities by building a first-mover advantage (Suarez \& Lanzolla, 2007). Such competence positively impacts followers' strategic change and their adaptability to new challenges. The hub firm then acts as a prototype of the network that captures major features of network actors when dealing with environmental dynamics. Such an image is constructed and maintained by uncertainty reduction that is self-conceptually relevant to the partners, thereby conferring confidence in how to behave and what to expect from the dynamic environment within which the partners find themselves and identify the relationships (Hogg \& Terry, 2000). As mutual interests are closely bound together, the hub firm's capability in dealing with environmental dynamics can significantly enhance partners' identification of the relationships, thereby promoting positive externalities (Munari et al., 2012). Furthermore, the distribution of environmental information deepens partner firms' cognition of current challenges, thus facilitating and legitimating the hub firm's behaviors in adjusting existing business relations.

\section{Proposition 6: The endurance of environmental dynamics helps create a relational identity} in ways that facilitate the enhancement of interfirm leadership. 


\subsubsection{The role of the hub firm as an explorer}

While a short-term partnership operates at the risk of moral hazard and opportunism, a long-term collaboration entails mutual trust and commitment, as well as anticipatable future interests. We propose that relational identity emerges based on both current benefits and the expectation of future offerings. A demonstration of capability in exploring potential market opportunities and novel technologies provides evidence of a hub firm's commitment to the future, thereby strengthening its status as a network leader.

Development of novel technologies. While partner firms may migrate to competing networks or relationships for more interests (e.g., Feng \& Lu, 2012), the development of novel technologies helps to maintain capability advantage within the network, and also to deepen partners' perception and identification of the current relationships by stimulating new inner interactions, enhancing competence-based benefits, and reducing governance-based risks (Vanhaverbeke et al., 2012).

Firstly, novel technologies benefit partner firms by providing them with opportunities to move toward a brighter future. The shadow of the future is acknowledged as a driver of enduring collaboration (Parkhe, 1993). A potential increase in gains positively impacts current behavior patterns (e.g., Chen \& Turut, 2013). This could stimulate partners' selective perception, evaluation, and interpretations of the network relationships in terms of the meanings for themselves (Scott \& Lane, 2000). Because the partners perceive and interpret presented relationships, they are supposed to involve in self-construction processes to fit well with the hub firm's development of novel technologies. When they perceive an overlap between self-identity and the cognitive image of their relationships with the hub firm, they identify these relationships (Scott \& Lane, 2000). This highlights the importance of the hub 
firm's leadership in terms of technology integration and coordination (Cantwell \& Janne, 1999).

Secondly, the development of novel technologies highlights the importance of the hub firm as the core of knowledge creation and distribution. The exploration of new technology areas normally requires outsiders' involvement and investment. The potential for improving technologies stimulates obedience among the partners by enhancing their technology dependence. A hub firm not only acts as a facilitator of knowledge exchange between itself and the partners, but also plays a leading role in promoting knowledge flow between partners (Lipparini et al., 2014), thus demonstrating a knowledge-mediation function for the whole network (Munari et al., 2012). Thereafter, the hub firm creates a capability-based structural differentiation of itself and the partners, and exerts influence over the partners by virtue of being prototypical which makes them automatically comply through self-conception (Hogg \& Terry, 2000). Hence, by introducing external technological novelties into the network, a hub firm can promote collective learning processes and shape partners' relational identity.

Proposition 7: The development of novel technologies helps create a relational identity in ways that facilitate the enhancement of interfirm leadership.

Exploration of new market opportunities. New market opportunities are closely associated with marginal interest because increased customers dilute initial investments and fixed costs. However, the development of such opportunities may also induce additional commitments and risks to the hub firm, suggesting that the capabilities of opportunity development and utilization are crucial to the efficiency of exploration (Lynn, Morone, \& Paulson, 1996). During the realization of value stemming from new market development, the hub firm's capabilities and the corresponding benefits one may obtain can be better perceived by the partners. This leads to partners' increased expectations which may prove self-fulfilling in 
influencing their initial behaviors (Sluss \& Ashforth, 2007), thus contributing to their identification of the relationships.

Further, increased market opportunities enhance partners' dependence on the network. Munari et al (2012) have demonstrated that a larger difference in size and the ability to control valuable resources result in a higher extent of dependence asymmetry. As new market opportunities fully stem from the hub firm, it will inevitably reinforce partners' identification of the relationships. Under such circumstances, an escalation of commitment from partners (i.e., investing more relational assets) can be expected.

Finally, the exploration of new market opportunities provides a hub firm with the potential to extend network ties and, in turn, leads to its more central position. A new market opportunity requires more participants for fulfilling the tasks, thus extending external relationships (Provan et al., 2007) and demonstrating a more central position for the hub firm (Kogut, 2000). For example, Alibaba, a world leading online shopping platform owner from China, has tried a series of market opportunities including group-buying and customer-to-business services, thereby contributing to the enhancement of a centralized eco-network. Also, increasing network ties enhances the likelihood of developing new collaborations between partners. According to Scott and Lane (2000), this will shape a desired image of the hub firm in bridging different network participants. Because the benefits of market exploration are salient and accessible to the partners, the identity of participation becomes well established. The hub firm provides the partners with more indirect ties and thus will extend the partners' relational identity and lead to increased leadership (Sydow \& Windeler, 1998).

Proposition 8: The exploration of new market opportunities helps create a relational identity in ways that facilitate the enhancement of interfirm leadership. 


\subsection{The factors influencing the hub firm's pursuit of interfirm leadership}

We now focus on contingencies that affect the mechanism through which the hub firm's actions influence relational identity and then interfirm leadership, including relationship duration, dependence asymmetry, and competitive intensity. The three factors have been identified to have implications for interfirm interaction and long-term relationship in previous studies (Gardet \& Mothe, 2011; Gulati \& Sytch, 2007; Zhou \& Li, 2012). A focus on these factors can help improve the understanding of the mechanism through which a hub firm obtains interfirm leadership. Specifically, relationship duration refers to routines being described as relationship-specific assets (Kotabe, Martin, \& Domoto, 2003), which has implications to successful knowledge management (Asanuma, 1998). It may then affect the extent to which a hub firm's actions benefit its partners and shape positive perceptions. Dependence asymmetry promotes partners to develop close relationships with the hub firm, thereby leading to increased resource commitment and involvement (Emerson, 1962; Rusbult et al., 1991). It could then influence partners' responses and recognition of the hub firm's actions. We thus argue that relationship duration and dependence asymmetry moderate the relationship between hub firm's actions and relational identity. Competitive intensity relates to a hub firm's performance in its final market, which could affect partners' motivation in developing persistent relationship. We thus argue that competitive intensity will influence the relationship between relational identity and interfirm leadership. When discussing the moderating roles of relationship duration and dependence asymmetry, we differentiate between directing and integration activities and exploration actions in that the former represents strategies for current value creation, while the latter concerns strategies for potential achievements. In so doing, we could clearly identify the moderating effects of relationship duration and dependence asymmetry on the relation between activities and relational identity. We then discuss the moderating role of competitive intensity in the relation 
between relational identity and interfirm leadership.

\subsubsection{Relationship duration}

Relationship duration is defined as time span of a collaborative relationship since its first establishment. It is suggested that relationship duration acts as a means to affect the closeness and frequency of interactions between partners (Gulati \& Sytch, 2007). Because the collaborative strategies and aims normally change over time (e.g., Gardet \& Mothe, 2011), a partner firm in different collaboration stages may have different perceptions on the hub's behaviors, which may have an impact on the shape of relational identity (Table 1).

When a collaborative relationship has lasted for a short span of time, the collaboration between the hub firm and its partners remains unstable. It is also likely that both sides of the relationship need to frequently adjust their ways of coordinating with each other because of the lack of established coordination routine (cf. Gardet \& Mothe, 2011). Moreover, the partners may expect increasing attention and involvement from the hub firm so as to strengthen the relationship. Given this situation, a guidance or integration behavior by the hub firm could easily obtain legitimacy, which in turn, increases the partners' identification of the relationship. As the collaboration goes on, however, the marginal benefits obtained from the hub firm's directing or integrating activities may demonstrate a significant decrease. This would lower the partners' expectations for the hub firm's guidance or integration behaviors, thereby decreasing the identification with their collaborative relationships. Especially for directing activities, an extended relationship would promote the partner firms' status and capability increase (e.g., Gnyawali \& Madhavan, 2001; Koschmann et al., 2012), enlarging the opportunities for which the partners seek new collaborations with other hub firms. This would lead to decreasing extent of relational identity (Sluss \& Ashforth, 2007). Therefore, we argue that relationship duration negatively moderates the relationship between the activities a hub firm conducts to demonstrate the roles of director and integrator and relational identity. 
For the activities of exploration, in contrast, relational duration may exert different impacts. Exploration activities represent commitments to the future. During the early stage of collaboration, partner firms may devote increasing energy to stabilizing the relationship rather than exploring new opportunities (cf. Gawer and Phillips, 2013). However, the attention to the exploration of new markets or technologies will increase if the collaboration is increasingly deepened because partners with a stable collaborative relationship may seek opportunities to expand this relationship. In this sense, relationship duration will positively moderate the relationship between exploration activities and relational identity.

Proposition 9: Relationship duration will negatively moderate the relationship between directing and integration activities and relational identity, but will positively moderate the relationship between exploration activities and relational identity.

\subsubsection{Dependence asymmetry}

Preffer and Salancik (1978: 40) defined interdependence as a phenomenon that "exists whenever one actor does not entirely control all of the conditions necessary for the achievement of an action or for obtaining the outcome desired from the action". According to Gulati and Sytch (2007), relationships characterized by balanced dependence are rare, and it is prevalent that an actor is more dependent on the other, i.e., dependence asymmetry, leading to 'net-positive dependence'.

Dependence asymmetry refers to the controlling nature of the relationship, suggesting an imbalanced state in which the partner gives heightened attention to the responses and attitudes of the hub firm (Emerson, 1962). When the hub firm devotes high inputs into the relationship, it will gain affirmation and aspiration, thereby demonstrating a satisfactory business tie. In this sense, dependence asymmetry will strengthen the partner's perception of the hub firm's directing and integration activities. Moreover, the higher the extent of dependence asymmetry, the more likely the partners expect extensive interactions with the 
hub firm, and thus the more effective the hub firm's directing and integration activities will be in increasing the partner's identification of the relationship (Lawler \& Yoon, 1996). Hence, dependence asymmetry will positively moderate the relationship between directing and integration activities and relational identity.

Dependence asymmetry may also affect the extent to which a partner bonds with the hub firm. When the level of dependence asymmetry is high, the partner either has significantly less strategic resources or holds substantially lower structural position than the hub firm, both of which result in difficulties for the partner to maintain a stable relationship (Casciaro \& Piskorski, 2005). In such case, the partner would pay little attention to the hub firm's exploration activities because its very concern is to ensure the persistence of the collaboration. Therefore, the higher the extent of dependence asymmetry, the more likely the partner will devote decreasing attention to the hub firm's exploration activities, and thus the less likely these activities will promote identification of the relationship (see Table 1 for detailed explanations of each of the seven actions).

Proposition 10: Dependence asymmetry will positively moderate the relationship between directing and integration activities and relational identity, but will negatively moderate the relationship between exploration activities and relational identity.

\subsubsection{Competitive intensity}

Competitive intensity demonstrates the intensiveness of market competition, referring to phenomenon such as promotion wars and competitive responses (Zhou \& Li, 2012). We argue that competitive intensity will affect the relationship between relational identity and interfirm leadership. Specifically, a market with high extent of competitive intensity will increase the risk of collaboration with a specific hub firm, which in turn, reduces the extent to which relational identity might encourage shared cognition and vision (Hogg \& Reid, 2006). It is argued that relational identity is associated with the willingness to build a long-term 
relationship (Ahearne, Bhattacharya, \& Gruen, 2005; Homburg, Wieseke, \& Hoyer, 2009), and strong competitive pressure would underscore the importance of such relational identity (cf. Haumann et al., 2014). Nevertheless, fierce competition might affect the market share of the hub firm, making its advantage unsustainable. Under such circumstances, relational identity may fail to stimulate deep interaction and participation as it would increase the partner firm's risk of financial loss (cf. Lee et al., 2015), which subsequently predicts lowered expectation of following the hub firm's lead. Moreover, fierce competition may accelerate the hub firm's strategic adjustment, which puts increasing financial pressure on the partner firm, thereby decreasing the extent to which relational identity could encourage commitment and follow. In this sense, the positive effect of relational identity on the enhancement of interfirm leadership will be weakened.

Proposition 11: Competitive intensity negatively moderates the relationship between relational identity and interfirm leadership.

\section{Discussion}

Network orchestration as an emerging field has been drawn increasing attention (Capaldo, 2007; Dhanaraj \& Parkhe, 2006; Paquin \& Howard-Grenville, 2013). While we believe that scholars have explored crucial issues in network strategy and value co-creation, existing studies fail to explain how a hub firm performs to secure the enhancement of its leadership. Given relationship asymmetries and actors' initiatives within networks (Gnyawali \& Madhavan, 2001; Lee et al., 2015), the hub firm as a network leader must take special care of individual properties and behaviors, as well as leader-follower interactions.

In this paper we argue that interfirm leadership rests in the process of shaping relational identity. Following this, we have identified three roles a hub firm may play to highlight its leadership status, namely director, integrator, and explorer, and seven actions taken to shape 
the partners' relational identity: involvement in partners' problem-solving processes, guidance on partners' goal-framing, the inclusion of diverse interests in decision-making, the pursuit of synergy in knowledge integration, the endurance of environmental dynamics, the exploration of new market opportunities, and the development of novel technologies. While it is desirable that a hub firm plays all three leader roles, interfirm leadership may also emerge in situations in which the hub firm only operates in one or two roles. This is because the partners' perception of network activities can be different at different times, across different contexts, and for different strategic objectives. The seven types of actions demonstrate major, but certainly not all, approaches a hub firm may take to orchestrate interfirm activities.

We have also identified several moderators in the mechanism through which interfirm leadership emerges and grows including relationship duration, dependence asymmetry, and competitive intensity. Specially, relationship duration will negatively moderate the relationship between directing and integration activities and relational identity, but will positively moderate the relationship between exploration activities and relational identity; In contrast, dependence asymmetry will positively moderate the relationship between directing and integration activities and relational identity, but will negatively moderate the relationship between exploration activities and relational identity. We also suggest that competitive intensity negatively moderates the relationship between relational identity and interfirm leadership.

This paper offers several important contributions that develop the literature on network orchestration and interfirm relationships. First, we extend current studies on interfirm networks by exploring leadership enhancement of hub firms. While some work in network areas highlighted the role of the hub firm as a leader (Paquin \& Howard-Grenville, 2013; Provan et al., 2007) and some studies on leadership explored the effect of interfirm leadership on network performance (Gawer \& Cusumano, 2002; Perrons, 2009), our work moves one 
step further, examining how leadership can be shaped. Our approach provides a novel insight into understanding network activities and outcomes, especially given that most hub firms consider network orchestration as a measure to manage interfirm processes and behaviors rather than a long-term strategy. The practical implication of this insight is that partner firms have the choice of collaborating with certain hub firms instead of others. As followers sometimes do not have the opportunities to select network leaders, such preference may significantly affect investment and commitment in value co-creation.

Second, we integrate a social identification perspective into interfirm network orchestration, examining the shape of partner firms' relational identity in terms of their relationships with the hub firms. Prior studies have drawn special attention to orchestration strategies a hub firm may introduce to ensure high network performance (Doz et al., 2000; Vanhaverbeke et al., 2012; Paquin \& Howard-Grenville, 2013), yet little has been done to examine how a hub firm's orchestration strategies stimulate partners' identification of the collaborative relationships. Our study indicates that hub firms' directing, integrating, and exploring behaviors have an impact on the shape of partners' relational identity. We offer a framework that explains how role-adoption and corresponding behaviors help to shape relational identity and thus, facilitate the emergence of interfirm leadership. The most fundamental implication of our framework is that position and capability advantages are not enough for managing network members. By exploring the role of joint activities in the formation of relational identity, we recognize the fundamentally social nature of network orchestration. We emphasize that network orchestration should not only be seen as behaviors or processes, but also as psychological interactions that shape subjective judgment. This perspective can be helpful in reframing Dhanaraj and Parkhe's (2006) deliberation on network orchestration, and also provides an alternative approach to enhancing the effectiveness of network activities. For managers from the hub firm, it is important to avoid 
excessive use of network power. Attention should be given to both what kinds of actions can be taken and what kinds of cognitive reflection on such actions can be expected.

Third, we also contribute to literature by identifying contingencies in the process of leadership emergence. We suggest that the effects of directing and integration activities on relational identity will be stronger when relationship duration is longer, but will be weaker when the extent of dependence asymmetry is higher; in comparison, the effects of exploration activities on relational identity will be weaker when relationship duration is longer, but will be stronger when the extent of dependence asymmetry is higher. In addition, our analysis suggests competitive intensity will negatively moderate the relationship between relational identity and interfirm leadership. The contingencies identified in this study help deepen our understanding of the mechanism through which a hub firm fosters relational identity to enhance its interfirm leadership.

One issue that needs to be solved in future research is how we conduct empirical studies to test the ideas developed in this paper. Because these ideas refer to a two-sided interaction, one major challenge would be to examine the psychological states and perceptions of the followers when facing the hub firm's actions. We would suggest that future work starts with qualitative analysis designed to reflect the behavioral consequences of such actions, with the ambition of investigating the interactions between actors within the network. Follow-up studies could more precisely test the model developed in the former stages.

While our study highlights the role of relational identity in the enhancement of interfirm leadership, another opportunity for future research would be to explore the mechanisms through which partner firms accept the hub firm's leadership. This is especially important since our study of relational identity implies that leadership is more accepted than granted. Along this line of consideration, one could conduct longitudinal studies, examining the dynamic processes in which the hub firm's interfirm leadership changes with the 
enhancement of the partners' relational identity.

Our study also has a limitation of reversed causality. While we suppose that orchestration actions have an impact on the shape of relational identity and then the enhancement of leadership, there is a concern that interfirm leadership may also influence relational identity and then the actions being taken. Because our causal relationship of action and identity is developed based on different actors (the hub firm's actions and the partners' identity) rather than the same one, it could help to alleviate this concern to some extent. Moreover, the enhancement of interfirm leadership represents a recursive process in which interfirm leadership will be both the outcome and also the predictor of the seven actions and relational identity. While the lack of longitudinal data makes it unlikely that we explore such a dynamic process, our treatment of focusing only on a sequential relationship from actions to interfirm leadership may at least improve our understanding of the mechanism through which interfirm leadership emerges and grows. Still, future research will have to overcome this limitation by conducting a robust research design.

We have put forward seven practices that help to shape relational identity, without considering their joint effects on the enhancement of interfirm leadership. A promising direction would be to examine how these practices work in combination to secure the enhancement of interfirm leadership. For example, in the case of a stable environment, the inclusion of diverse interests in decision-making would be better perceived than the endurance of environmental dynamics. As this issue may relate to the steps a hub firm would take to enhance interfirm leadership, future research will need to fill this gap.

Finally, we conducted our analysis at the within-network level, without taking into consideration elements that differentiate one network from another. In fact, we have chosen to focus on the locus of network orchestration with an underlying premise that market competition happens at the network level. However, we did not mention specific issues that 
define characteristics and contexts of a network, such as the scale of a network, the number of actors, and the network's centrality and density. The exploration of between-network elements that may affect interfirm leadership represents another promising research direction stemming from this paper.

\section{Conclusion}

Existing literature has paid increasing attention to network orchestration and leadership of the hub firms, yet little has been done to examine how network orchestration secures the enhancement of interfirm leadership. Drawing on social identity perspective, this study explores how a hub firm orchestrate its partner firms to enhance interfirm leadership. We argue that the enhancement of interfirm leadership rests in the process in which relational identity shapes. We have identified three roles of the hub firm, namely director, integrator, and explorer, and offered seven practices that can shape relational identity, and then, interfirm leadership. Though not exhaustive, these practices provide a starting point for further exploration of the enhancement of interfirm leadership. For different partners and in different situations, the importance of the seven practices can vary in terms of shaping relational identity. Meanwhile, the hub firm may have to give more prominence to certain role(s) in different stages and contexts so that interfirm leadership can be acknowledged. We also identify the moderating effects of relationship duration and dependence asymmetry in the relationships between actions and relational identity and the moderating role of competitive intensity in the relationship between relational identity and interfirm leadership, thereby providing us with a contingent perspective of leadership emergence. While we borrow the conceptualization of leadership and identity from individual level, we have applied them into our theorizing in the interfirm context, which is consistent with existing studies (e.g., Gawer \& Phillips, 2013; Zeng \& Chen, 2003). In this sense, our conceptualization of the shape of 
relational identity and the enhancement of interfirm leadership could be applicable to interfirm settings. As a conceptual piece of work, we hope our framework and analysis can offer additional insights in understanding the mechanism through which interfirm leadership can be enhanced and stimulate further discussion in this area.

\section{References}

Ahearne, M., Bhattacharya, C. B., \& Gruen, T. (2005). Antecedents and consequences of customer-company identification: expanding the role of relationship marketing. Journal of Applied Psychology, 90(3), 574-585.

Anderson, J. C., Håkansson, H., \& Johanson J. (1994). Dyadic business relationships within a business network context. Journal of Marketing, 58(4), 1-15

Ariño, A., \& Ring, P. S. (2010). The role of fairness in alliance formation. Strategic Management Journal, 31, $1054-1087$.

Asanuma B. 1989. Manufacturer-supplier relationships in Japan and the concept of relation-specific skill. Journal of the Japanese and International Economies, 3: 1-30.

Bitektine, A. (2011). Toward a theory of social judgments of organizations: the case of legitimacy, reputation, and status. Academy of Management Review, 36(1), 151-179.

Brickson, S. L. (2007). Organizational identity orientation: The genesis of the role of the firm and distinct forms of social value. Academy of Management Review, 32(3), 864-888

Cantwell, J., \& Janne, O. (1999). Technological globalisation and innovative centres: the role of corporate technological leadership and locational hierarchy. Research Policy, 28, 119-144.

Capaldo, A. (2007). Network structure and innovation: the leveraging of a dual network as a distinctive relational capability. Strategic Management Journal, 28, 585-608.

Casciaro, T., \& Piskorski, M. J. (2005). Power imbalance, mutual dependence, and constraint absorption: A closer look at resource dependence theory. Administrative Science Quarterly 50: 167-199.

Chen, Y., \& Turut, Ö. (2013). Context-dependent preferences and innovation strategy. Management Science, 59(12), $2747-2765$.

Cook, K. S., \& Emerson, R. M. (1978). Power, equity and commitment in exchange networks. American Sociological Review, 43, 721-739.

Czarniawska, B. (1997). Narrating the organization: Dramas of institutional identity. Chicago: University of Chicago Press.

De Reuver, M., \& Bouwman, H. (2012). Governance mechanisms for mobile service innovation in value networks. Journal of Business Research, 65, 347-354.

Dhanaraj, C., \& Parkhe, A. (2006). Orchestrating innovation networks. Academy of Management Review, 31(3), 659-669.

Doz, Y. L., Olk, P. M., \& Ring, P. S. (2000). Formation processes of R\&D consortia: which path to take? Where does it lead? Strategic Management Journal, 21, 239-266.

Dunbar, R. I. M. (2003). The social brain: Mind, language, and society in evolutionary perspective. Annual Review of Psychology, 32, $163-181$.

Dutton, J. E., Dukerich, J. M., \& Harquail, C. V. (1994). Organizational images and member identification. Administrative Science Quarterly, 39, 239-263.

Dyer, J. H., \& Nobeoka, K. (2000). Creating and managing a high-performance knowledge-sharing network: the Toyota case. Strategic Management Journal, 21, 345-367. 
Dyer, J. H., \& Singh, H. (1998). The relational view: Cooperative strategy and sources of interorganizational competitive advantage. Academy of Management Review, 23(4), 660-679.

Emerson, R. M. (1962). Power-dependence relations. American Sociological Review, 27(1), 31-41.

Feng, Q., \& Lu, L. X. (2012). The strategic perils of low cost outsourcing. Management Science, 58(6), 1196-1210.

Folta, T. B. (1998). Governance and uncertainty: the tradeoff between administrative control and commitment. Strategic Management Journal, 19, 1009-1028.

Frances, J., \& Garnsey, E. (1996). Supermarkets and suppliers in the United Kingdom: System integration, information and control. Accounting, Organizations and Society, 22(6), 591-610.

Gal-Or, E. (1985). First mover and second mover advantages. International Economic Review, 26, 649-653.

Gardet, E., \& Mothe C. The dynamics of coordination in innovation networks. European Management Review, 8, 213-229

Gaski, J. F. (1984). The theory of power and conflict in channels of distribution. Journal of Marketing, 48, 9-29.

Gawer, A., \& Cusumano, M.A. (2002). Platform leadership: How Intel, Microsoft, and Cisco drive industry innovation. Boston,

Massachusetts, Publisher: Harvard Business School Press.

Gawer, A. (2014). Bridging differing perspectives on technological platforms: Toward an integrative framework. Research Policy, 45, 1239-1249.

Gawer A., \& Phillips N. (2013). Institutional work as logics shift: the case of Intel's transformation to platform leader. Organization Studies, 34(8), 1035-1071

Gioia, D. A., Schultz, M., \& Corley, K. G. (2000). Organizational identity, image, and adaptive instability. Academy of Management Review, $25(1), 63-81$.

Gnyawali, D. R., \& Madhavan, R. (2001). Cooperative networks and competitive dynamics: a structural embeddedness perspective. Academy of Management Review, 26(3), 431-445.

Grönroos, C. (2011). A service perspective on business relationships: The value creation, interaction and marketing interface. Industrial Marketing Management, 40(3), 240-247.

Gulati, R., \& Singh, H. (1998). The architecture of cooperation: managing coordination costs and appropriation concerns in strategic alliances. Administrative Science Quarterly, 43 (4), 781-814.

Gulati, R., \& Sytch, M. (2007). Dependence asymmetry and joint dependence in interorganizational relationships: Effects of embeddedness on a manufacturer's performance in procurement relationships. Administrative Science Quarterly, 52, 32-69.

Hagedoorn, J. (1995). A note on international market leaders and networks of strategic technology partnering. Strategic Management Journal, 16, 241-250.

Haumann, T., Quaiser, B., Wieseke, J., \& Rese, M. (2014). Footprints in the sands of time: a comparative analysis of the effectiveness of customer satisfaction and customer-company identification over time. Journal of Marketing, 78(6), 78-102.

Hogg, M. A., \& Reid, S. A. (2006). Social identity, self-categorization, and the communication of group norms. Communication Theory, 16, $7-30$.

Hogg, M. A., \& Terry, D. J. (2000). Social identity and self-categorization processes in organizational contexts. Academy of Management Review, 25(1), 121-140

Hogg, M. A., van Knippenberg, D., \& Rast, D. E. (2012). Intergroup leadership in organizations: leading across group and organizational boundaries. Academy of Management Review, 37(2), 232-255.

Homburg, C., Wieseke, J., \& Hoyer, W. D. (2009). Social identity and the service-profit chain. Journal of Marketing, 73(2), 38-54. 
Kenis, P., \& Knoke, D. (2002). How organizational field networks shape interorganizational tie-formation rates. Academy of Management Review, 27(2), 275-293.

Kogut, B. (2000). The network as knowledge: Generative rules and the enhancement of structure. Strategic Management Journal, 21, $405-425$.

Kogut, B., \& Zander, U. (1996). What Firms Do? Coordination, Identity, and Learning. Organization Science, 7(5), $502-518$.

Koschmann, M. A., Kuhn, T. R., \& Pfaffer, M. D. (2012). A communicative framework of value in cross-sector partnerships. Academy of Management Review, 37(3), 332-354.

Lee, S.-H., Mun, H. J., \& Park, K. M. (2015). When is dependence on other firms burdensome? The effect of asymmetric dependence on internet firm failure. Strategic Management Journal, 36, 2058-2074.

Lindenberg, S. (2008). Social rationality, semi-modularity and goal-framing: What is it all about? Analyse und Kritik, $30,669-687$.

Lindenberg, S., \& Foss, N. J. (2011). Managing joint production motivation: the role of goal framing and governance mechanisms. Academy of Management Review, 36(3), 500-525.

Lipparini, A., Lorenzoni, G., \& Ferriani, S. (2014). From core to periphery and back: a study on the deliberate shaping of knowledge flow in interfirm dyads and networks. Strategic Management Journal, 35, 578-595.

Lorenzoni, G., \& Baden-Fuller, C. (1995). Creating a strategic center to manage a web of partners. California Management Review, 37, $146-163$.

Luo, Y. (2008). Procedural fairness and interfirm cooperation in strategic alliances. Strategic Management Journal, $29(1), 27-46$.

Lynn, G. S., Morone, J., \& Paulson, A. S. (1996). Marketing and discontinuous innovation: the probe and learn process. California Management Review, 38 (3), 8-37.

McEvily, B., \& Marcus, A. (2005). Embedded ties and the acquisition of competitive capabilities. Strategic Management Journal, 26, $1033-1055$.

Merton, R. K. (1936). The unanticipated consequences of purposive social action. American Sociological Review, 1(6), 894-904.

Moore, J. F. (1993). Predators and prey: a new ecology of competition. Harvard Business Review, May-June, 75-86.

Müller-Seitz, G. (2012). Leadership in interorganizational networks: A literature review and suggestions for future research. International Journal of Management Reviews, 14, 428-443.

Munari, F., Sobrero, M., \& Malipiero, A. (2012). Absorptive capacity and localized spillovers: focal firms as technological gatekeepers in industrial districts. Industrial and Corporate Change, 21(2), 429-462.

Paquin, R. L., \& Howard-Grenville, J. (2013). Blind dates and arranged marriages: Longitudinal processes of network orchestration. Organization Studies, 34(11), 1623-1653.

Parkhe, A. (1993). Strategic alliance structuring: A game theoretic and transaction cost examination of interfirm cooperation. Academy of Management Journal, 36, 794-829.

Perrons, R. K. (2009). The open kimono: How Intel balances trust and power to maintain platform leadership. Research Policy, 38, $1300-1312$.

Pfeffer, J., \& G. R. Salancik GR. (1978). The external control of organizations: A resource dependence perspective. New York: Harper \& Row.

Provan, K.G., \& Kenis, P. (2008). Modes of network governance: structure, management, and effectiveness. Journal of Public Administration Research and Theory, 18, 229-252.

Provan, K. G., Fish, A., \& Sydow J. (2007). Interorganizational networks at the network level: A review of the empirical literature on whole 
networks. Journal of Management, 33, 479-516.

Ring, P. S., \& Van de Ven, A. H. (1992). Structuring cooperative relationships between organizations. Strategic Management Journal, 13, $483-498$.

Rowley, T. J., \& Moldoveanu, M. (2003). When will stakeholder groups act? An interest- and identity-based model of stakeholder group mobilization. Academy of Management Review, 28(2), 204-219.

Rusbult, C. E., Verette, J., Whitney, G. A., \& Slovik, L. F. (1991). Accommodation processes in close relationships: Theory and preliminary empirical evidence. Journal of Personality and Social Psychology, 60, 53-78.

Savage, G., Nix, T., Whitehead, C., \& Blair, J. (1991). Strategies for assessing and managing stakeholders. Academy of Management Executive, 5(2), 61-75.

Schreiner, M., Kale, P., \& Corsten, D. (2009). What really is alliance management capability and how does it impact alliance outcomes and success? Strategic Management Journal, 30, 1395-1419.

Scott, S. G., \& Lane, V. R. (2000). A stakeholder approach to organizational identity. Academy of Management Review, 25(1), 43-62. Sluss, D. M., \& Ashforth, B. E. (2007). Relational identity and identification: Defining ourselves through work relationships. Academy of Management Review, 32(1), 9-32.

Sluss, D. M., \& Ashforth, B. E. (2008). How relational and organizational identification converge: Processes and conditions. Organization Science, 19(6), 807-823.

Suarez, F. F., \& Lanzolla, G. (2007). The role of environmental dynamics in building a first mover advantage theory. Academy of Management Review, 32(2), 377-392.

Sydow, J., Lerch, F., Huxham, C., \& Hibbert, P. (2011). A silent cry for leadership: organizing for leading (in) clusters. Leadership Quarterly, 22, 328-343.

Sydow, J., \& Windeler, A. (1998). Organizing and evaluating interfirm networks: a structurationist perspective on network processes and effectiveness. Organization Science, 9, 265-284.

Tajfel, H. (1974). Social identity and intergroup behaviour. Social Science Information, 13, 65-93.

Tellis, G. J., \& Golder P. N. (1996). First to market, first to fail? Real causes of enduring market leadership. Sloan Management Review, $37(2), 65-75$.

Uzzi, B. (1997). Social structure and competition in interfirm networks: The paradox of embeddedness. Administrative Science Quarterly, $42(1), 35-67$.

Vanhaverbeke, W., Gilsing, V., \& Duysters, G. (2012). Competence and governance in strategic collaboration: The differential effect of network structure on the creation of core and noncore technology. Journal of Product Innovation Management, 29(5), 784-802.

Walumbwa, F. O., \& Hartnell, C. A. (2011). Understanding transformational leadership-employee performance links: The role of relational identification and self-efficacy. Journal of Occupational and Organizational Psychology, 84, 153-172.

Wright, S. C., Aron, A., McLaughlin-Volpe, T., \& Ropp, S. A. (1997). The extended contact effect: Knowledge of crossgroup friendships and prejudice. Journal of Personality and Social Psychology, 73, 73-90.

Zaheer, A., \& Bell, G. G. (2005). Benefiting from network position: firm capabilities, structure holes, and performance. Strategic Management Journal, 26, 809-825.

Zajac, E. J., Kraatz, M. S., \& Bresser, R. K. F. (2000). Modeling the dynamics of strategic fit: a normative approach to strategic change. Strategic Management Journal, 21, 429-453.

Zeng, M., \& Chen X. P. (2003). Achieving cooperation in multiparty alliances: a social dilemma approach to partnership management. 
Academy of Management Review, 28(4), 587-605.

Zhou, K. Z., \& Li, C. B. (2012). How knowledge affects radical innovation: knowledge base, market knowledge acquisition, and internal knowledge sharing. Strategic Management Journal 33, 1090-102.

Zhu, H., \& Yoshikawa, T. (2015). Contingent value of direct identification: the role of government directors in monitoring and resource provision in an emerging economy. Strategic Management Journal, article in advance, available at:

http://onlinelibrary.wiley.com/doi/10.1002/smj.2408. 
FIGURE AND TABLE:

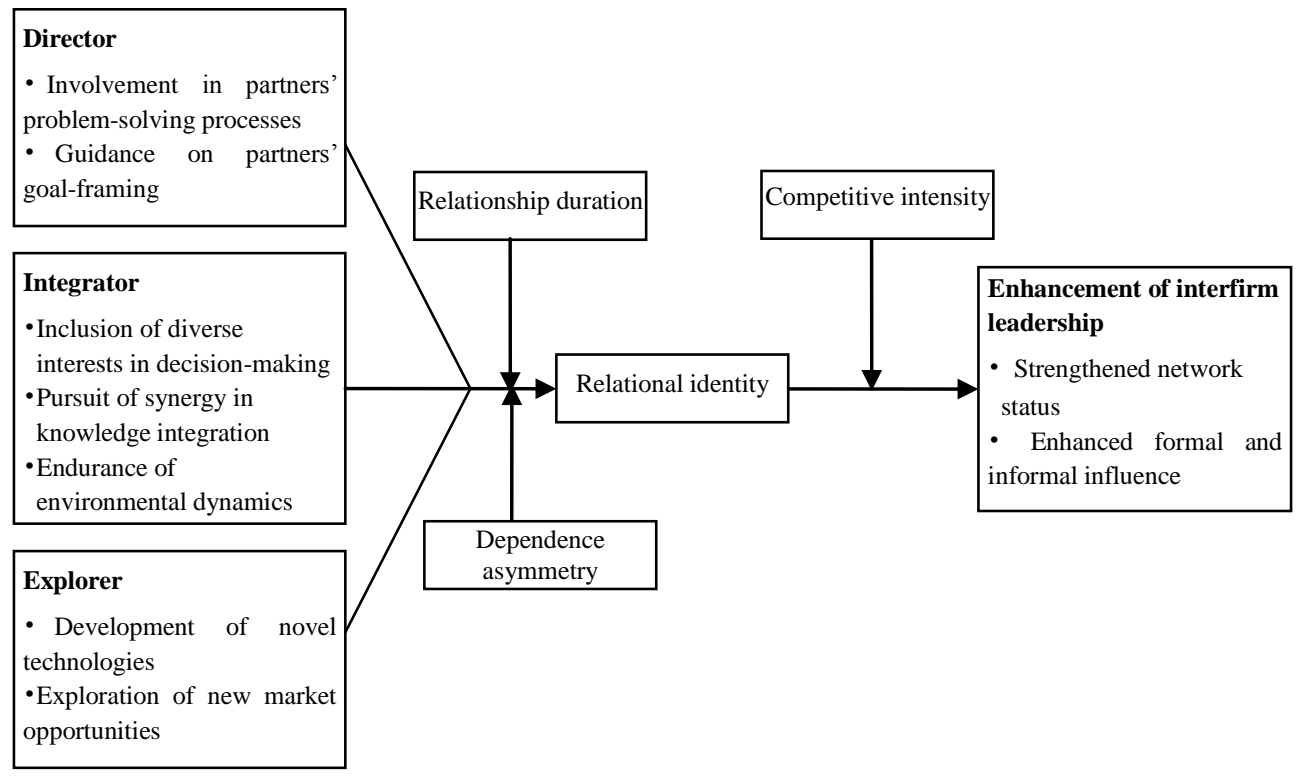

Figure 1 The enhancement of interfirm leadership

Table 1 The moderating effects of relationship duration and dependence asymmetry on the relationships between each action and relational identity

\begin{tabular}{|c|c|c|}
\hline Actions & The moderating effect of relationship duration & $\begin{array}{l}\text { The moderating effect of dependence } \\
\text { asymmetry }\end{array}$ \\
\hline $\begin{array}{l}\text { Involvement in partners' } \\
\text { problem-solving processes }\end{array}$ & $\begin{array}{l}\text { The longer the time span of a relationship, the } \\
\text { lower the marginal benefits obtained from the } \\
\text { hub firm's involvement in its partner's } \\
\text { problem-solving processes, thus the less likely } \\
\text { to shape relational identity }\end{array}$ & $\begin{array}{l}\text { The higher the extent of dependence } \\
\text { asymmetry, the more likely the hub firm's } \\
\text { involvement actions obtain affirmation, and the } \\
\text { more likely to shape relational identity }\end{array}$ \\
\hline $\begin{array}{l}\text { Guidance on partners' } \\
\text { goal-framing }\end{array}$ & $\begin{array}{l}\text { The longer the time span of a relationship, the } \\
\text { less likely the partner firm will benefit from the } \\
\text { hub firm's guidance on goal-framing, and thus } \\
\text { the more difficult to shape relational identity }\end{array}$ & $\begin{array}{l}\text { The higher the extent of dependence } \\
\text { asymmetry, the more likely the hub firm's } \\
\text { guiding actions promotes strategic fit between } \\
\text { partner firms, and the more likely to shape } \\
\text { relational identity }\end{array}$ \\
\hline $\begin{array}{l}\text { Inclusion of diverse interests } \\
\text { in decision-making }\end{array}$ & $\begin{array}{l}\text { As the collaboration goes on, the inclusion of } \\
\text { diverse interests becomes easier and more } \\
\text { usual, thereby decreasing its effect on the shape } \\
\text { of relational identity }\end{array}$ & $\begin{array}{l}\text { When the extent of dependence of asymmetry } \\
\text { is high, the inclusion of diverse interests may } \\
\text { lead the partner to increase its relationship } \\
\text { inputs, which leads to a high extent of } \\
\text { relational identity }\end{array}$ \\
\hline $\begin{array}{l}\text { Pursuit of synergy in } \\
\text { knowledge integration }\end{array}$ & $\begin{array}{l}\text { The longer the collaboration, the easier the } \\
\text { pursuit of synergy in knowledge integration, the } \\
\text { less likely such an action promotes the partner's } \\
\text { identification with the relationship }\end{array}$ & $\begin{array}{l}\text { The higher the extent of dependence } \\
\text { asymmetry, the more likely the pursuit of } \\
\text { synergy leads the partner firm to bond closely } \\
\text { with the hub firm, and thus the higher the } \\
\text { extent of relational identity }\end{array}$ \\
\hline $\begin{array}{l}\text { Endurance of environmental } \\
\text { dynamics }\end{array}$ & $\begin{array}{l}\text { As the collaboration goes on, the endurance of } \\
\text { environmental dynamics becomes a regular } \\
\text { feature of the relationship rather than an } \\
\text { advantage over other relationships, and its } \\
\text { effect on relational identity thus decreases }\end{array}$ & $\begin{array}{l}\text { When the extent of dependence asymmetry is } \\
\text { high, the endurance of environmental dynamics } \\
\text { leads to high willingness to increase } \\
\text { commitment to the relationship, which } \\
\text { promotes the shape of relational identity }\end{array}$ \\
\hline $\begin{array}{l}\text { Development of novel } \\
\text { technologies }\end{array}$ & $\begin{array}{l}\text { The longer the collaboration, the more likely } \\
\text { the development of novel technologies will } \\
\text { benefit the partner firm, and the more likely } \\
\text { such an action helps shape relational identity }\end{array}$ & $\begin{array}{l}\text { A high extent of dependence asymmetry leads } \\
\text { to the fact that a partner firm has to compete for } \\
\text { short-term benefits, decreasing the extent to } \\
\text { which the development of novel technologies } \\
\text { promotes the shape of relational identity }\end{array}$ \\
\hline $\begin{array}{l}\text { Exploration of new market } \\
\text { opportunities }\end{array}$ & $\begin{array}{l}\text { As the collaboration goes on, the endeavor of } \\
\text { exploring new market opportunities will be } \\
\text { likely to win returns, thereby promoting the } \\
\text { partner firm to shape relational identity }\end{array}$ & $\begin{array}{l}\text { A high extent of dependence asymmetry leads } \\
\text { to the fact that a partner firm has to compete for } \\
\text { short-term benefits, decreasing the extent to } \\
\text { which the exploration of new markets promotes } \\
\text { the shape of relational identity }\end{array}$ \\
\hline
\end{tabular}

